\title{
Genetic discontinuity in two high dispersal marine invertebrates in the northwest Atlantic
}

\author{
Anthony L. Einfeldt ${ }^{a}$, Felix Zhou ${ }^{a}$, and Jason A. Addison ${ }^{a \star}$ \\ ${ }^{a}$ Department of Biology, University of New Brunswick, P.O. Box 4400, Fredericton, NB E3B 5A3, Canada \\ *ja.addison@gmail.com
}

\begin{abstract}
Oceanic circulation patterns shape both the distribution of species and spatial patterns of intraspecific genetic variation by influencing passively dispersed marine invertebrates. In the northwest Atlantic, strong and consistent currents at the mouth of the Bay of Fundy are expected to restrict dispersal in this region, but the relationship between populations of high dispersal species along the surrounding coastal regions has been largely underrepresented in the phylogeographic literature. We analyzed phylogeographic patterns in two intertidal invertebrates with high dispersal abilities, Tritia obsoleta (Mollusca: Gastropoda) and Macoma petalum (Mollusca: Bivalvia), between Cape Cod and the Gulf of St. Lawrence using mitochondrial DNA (mtDNA). Hierarchical analysis of molecular variance revealed population structuring among regions defined by circulation patterns, highly divergent lineages within $M$. petalum, and strong concordant genetic subdivision in both species between the Bay of Fundy and Gulf of Maine. Our results suggest that the gyre at the mouth of the bay is influential in restricting alongshore dispersal, allowing genetic divergence between regions to arise through genetic drift. These findings are concordant with biogeographic and phylogeographic studies of other marine organisms, suggesting that the genetic isolation of widely distributed species may be a common feature of intertidal invertebrate communities in the Bay of Fundy.
\end{abstract}

Citation: Einfeldt AL, Zhou F, and Addison JA. 2017. Genetic discontinuity in two high dispersal marine invertebrates in the northwest Atlantic. FACETS 2: 160-177. doi: 0.1 I 39/facets-20 I 6-0044

Editor: Kristi M. Miller

Received: August 17, 2016

Accepted: November 23, 2016

Published: February 21, 2017

Copyright: (C) 2017 Einfeldt et al. This work is licensed under a Creative Commons

Attribution 4.0 International License (CC BY 4.0), which permits unrestricted use, distribution, and reproduction in any medium, provided the original author(s) and source are credited.

Published by: Canadian Science Publishing

Key words: phylogeography, mtDNA, genetics, marine invertebrate, Tritia obsoleta, Macoma petalum

\section{Introduction}

Environmental features play a primary role in defining range limits for many species, and in coastal marine systems distributional boundaries are narrowly concentrated over regions where currents converge, diverge, or form retention zones (Gaylord and Gaines 2000; Byers and Pringle 2006). Although community composition can abruptly change across such biogeographic breaks, these boundaries can remain semipermeable to some species, particularly those with pelagic larval development (e.g., Altman et al. 2013; Pappalardo et al. 2015). Limited dispersal in broadly distributed species acts to reduce the homogenizing effects of gene flow and provides an opportunity for populations to diverge through random genetic drift or local adaptation. By examining the scale to which populations are ecologically and evolutionarily independent, studies of coastal marine species across known biogeographic breaks can inform marine conservation and management plans and are critical to understanding the consequences of anthropogenic change (Harley et al. 2006). 
In the northwest Atlantic, biogeographic studies have identified major boundaries at Cape Hatteras, Cape Cod, and the mouth of the Bay of Fundy (Engle and Summers 1999; Wilkinson et al. 2009; Hale 2010; Pappalardo et al. 2015). Genetic studies of marine invertebrates spanning these boundaries show concordant patterns of population subdivision where coastal currents diverge at Cape Hatteras, and eddy-like currents at Cape Cod and the Bay of Fundy reduce alongshore transport of larvae (see Kelly et al. 2006; Altman et al. 2013; Govindarajan et al. 2015). Although some studies have sampled populations in the Gulf of Maine and along the Atlantic coast of Nova Scotia, few have focused on populations of species in the Bay of Fundy, where a persistent gyre at the mouth of the bay may reduce alongshore dispersal by enhancing the retention of larvae (Pettigrew et al. 2005). Two population genetic studies on mudflat species that lack planktonic larval development (Corophium volutator: Einfeldt and Addison 2013; Hediste diversicolor: Einfeldt et al. 2014) suggest that there is little or no gene flow between the Bay of Fundy and the Gulf of Maine. Although these results are consistent with reduced connectivity across this major biogeographic break, both species were recently introduced from Europe and thus may show patterns of genetic subdivision arising from independent founder events (Einfeldt and Addison 2015). Investigating species with high dispersal potential (i.e., species with pelagic larva) will help assess the degree to which the biogeographic break between the Bay of Fundy and the Gulf of Maine is a general feature limiting connectivity throughout the region.

The gastropod Tritia obsoleta (Say 1822; formerly Nassarius obsoletus, Ilyanassa obsoleta: Galindo et al. 2016) and the bivalve Macoma petalum (Valenciennes 1821) are widespread and abundant intertidal species endemic to marine and estuarine intertidal flats from Florida to the Gulf of St. Lawrence (GSL) (Scheltema 1964; Nikula et al. 2007). Reproduction and development in both species include a long-lived planktonic larval stage lasting 2-6 weeks (Scheltema 1967; Caddy 1969), and although there are exceptions, species with long-lived planktonic larvae generally possess greater dispersal potential than species with direct development (e.g., Havenhand 1995; Weersing and Toonen 2009). Genetic studies of both species along the Atlantic coast of North America from Florida to New Jersey reveal expected patterns of low among-population genetic differentiation, as is expected for species with pelagic larvae (T. obsoletus: Gooch et al. 1972; Díaz-Ferguson et al. 2010; M. petalum: Meehan 1985). As T. obsoletus and M. petalum are both endemic to the northwest Atlantic and have high dispersal potentials, comparative phylogeography of these species provides an opportunity to build on previous studies of direct developing species to further evaluate the permeability of the biogeographic break at the mouth of the Bay of Fundy.

In this study, we use patterns of mitochondrial DNA (mtDNA) diversity among northwest Atlantic populations of T. obsoleta and M. petalum to test the hypothesis that a persistent gyre at the mouth of the Bay of Fundy limits alongshore dispersal of larvae and reduces gene flow between regions. Populations within the Bay of Fundy are expected to be significantly different from populations both upstream along the Atlantic coast of Nova Scotia and downstream in the Gulf of Maine. In contrast, population genetic homogeneity across the biogeographic break would be consistent with extensive dispersal and high gene flow across the gyre at the mouth of the Bay of Fundy, implicating ecological differences as primary drivers of range limits (among species) and genetic divergence (within species) across this biogeographic break. By assessing the levels of genetic structure among species with high dispersal abilities, our results provide insight into the importance of dispersal limitation to the formation of the biogeographic break observed at the community level across the mouth of the Bay of Fundy.

\section{Materials and methods}

\section{Sampling, DNA extraction, amplification, and sequencing}

We collected T. obsoleta $(n=204)$ and M. petalum $(n=194)$ from 15 and 14 sites (respectively) along the Atlantic coast of North America between Stonington (Connecticut, USA) and L'Isle Verte 
(Quebec, Canada) between May 2011 and July 2014 (Fig. 1; Tables 1-2). Invertebrate specimens were collected under Special License No. 2012-79-01 (USA) and Section 52 licence SG-RHQ-14-091 (Canada). Samples were preserved in $95 \%$ ethanol and stored at $-20^{\circ} \mathrm{C}$ prior to DNA extraction. We extracted DNA from the foot tissue of both species using a cetyltrimethylammonium bromide (CTAB) protocol (Doyle and Doyle 1987).

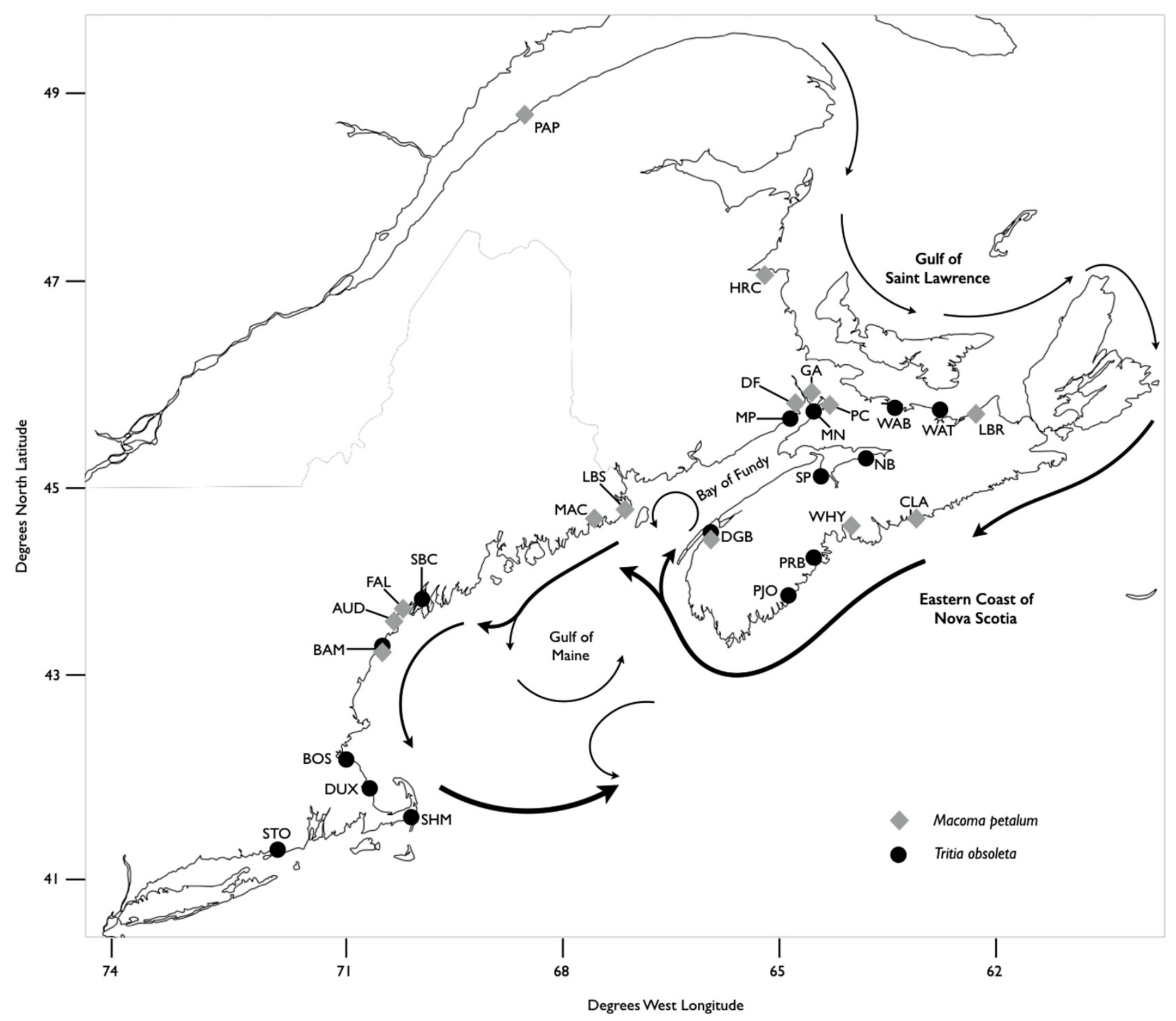

Fig. 1. Sampling locations of Tritia obsoleta and Macoma petalum in the northwest Atlantic (see Tables 1 and 2). Currents adapted from Aretxabaleta et al. (2008), Pettigrew et al. (2005), and Drinkwater and Gilbert (2004). Map data @2016 Mapbox (www.mapbox.com/about/maps/). AUD, Audubon; BAM, Beach Avenue; BOS, Boston; CLA, Clam Harbour; DGB, Digby; DF, Daniels Flat; DUX, Duxbury; FAL, Falmouth; GA, Grande Anse; HRC, Black River; LBR, Barneys River; LBS, Lubec; MAC, Machiasport; MN, Minudie; MP, Mary’s Point; NB, Noel Bay; PAP, Pointe-au-Père; PC, Pecks Cove; PJO, Port Joli; PRB, Petite Rivière Bridge; SBC, Strawberry Cove; SHM, Stage Harbour; SP, Starr's Point; STO, Stonington;WAB, Brule Harbour; WAT, Waterside; WHY, Whynachts Point. 
Table 1. Mitochondrial DNA (COI) diversity for Tritia obsoleta populations surveyed.

\begin{tabular}{|c|c|c|c|c|c|c|c|c|}
\hline & Degrees latitude & $n$ & $S$ & $H$ & $h$ & $\pi$ & Tajima's $D$ & Fu and Li's $F$ \\
\hline St. Lawrence & & 29 & 2 & 3 & 0.13547 & 0.0003 & -1.50906 & -2.36721 \\
\hline WAB & $45^{\circ} 44^{\prime} 24.36^{\prime \prime}$ & 15 & 0 & 1 & 0 & 0 & 0 & 0 \\
\hline WAT & $45^{\circ} 45^{\prime} 29.50^{\prime \prime}$ & 14 & 2 & 3 & 0.27473 & 0.00062 & -1.48074 & -1.97405 \\
\hline Eastern Nova Scotia & & 26 & 8 & 5 & 0.72 & 0.00757 & $2.05645^{\star}$ & 1.30087 \\
\hline PJO & $43^{\circ} 52^{\prime} 46.57^{\prime \prime}$ & 15 & 8 & 5 & 0.5619 & 0.00524 & -0.09034 & 0.24688 \\
\hline PRB & $44^{\circ} 14^{\prime} 9.82^{\prime \prime}$ & 11 & 2 & 2 & 0.50909 & 0.00222 & 1.50194 & 1.25816 \\
\hline Bay of Fundy & & 92 & 20 & 15 & 0.66197 & 0.00646 & -0.83275 & $-2.52714^{\star}$ \\
\hline DGB & $44^{\circ} 35^{\prime} 6.27^{\prime \prime}$ & 16 & 9 & 6 & 0.68333 & 0.00606 & 0.08492 & 0.38426 \\
\hline SP & $45^{\circ} 7^{\prime} 35.73^{\prime \prime}$ & 18 & 10 & 6 & 0.66667 & 0.00612 & -0.12811 & -0.39234 \\
\hline NB & $45^{\circ} 18^{\prime} 15.68^{\prime \prime}$ & 19 & 14 & 6 & 0.76608 & 0.00845 & -0.12432 & -0.55988 \\
\hline PC & $45^{\circ} 45^{\prime} 4.06^{\prime \prime}$ & 19 & 8 & 4 & 0.45029 & 0.0049 & -0.0647 & 0.17099 \\
\hline MP & $45^{\circ} 43^{\prime} 14.35^{\prime \prime}$ & 20 & 9 & 7 & 0.75263 & 0.007 & 0.90614 & 0.15957 \\
\hline Gulf of Maine & & 57 & 22 & 19 & 0.92669 & 0.01048 & 0.01825 & 1.06648 \\
\hline SBC & $43^{\circ} 48^{\prime} 49.96^{\prime \prime}$ & 11 & 11 & 5 & 0.83636 & 0.0104 & 1.15497 & 1.26582 \\
\hline BAM & $43^{\circ} 26^{\prime} 16.58^{\prime \prime}$ & 6 & 11 & 5 & 0.93333 & 0.01077 & 0.14539 & 0.22163 \\
\hline BOS & $42^{\circ} 15^{\prime} 27.61^{\prime \prime}$ & 11 & 12 & 5 & 0.85455 & 0.00985 & 0.43678 & 0.8187 \\
\hline DUX & $42^{\circ} 3^{\prime} 1.35^{\prime \prime}$ & 7 & 9 & 3 & 0.52381 & 0.00645 & -1.04329 & -1.08105 \\
\hline SHM & $41^{\circ} 39^{\prime} 44.68^{\prime \prime}$ & 14 & 18 & 10 & 0.95604 & 0.01192 & -0.14544 & 0.6079 \\
\hline STO & $41^{\circ} 20^{\prime} 7.28^{\prime \prime}$ & 8 & 12 & 6 & 0.92857 & 0.00967 & -0.21692 & 0.26106 \\
\hline Total & & 204 & 27 & 30 & 0.86004 & 0.00824 & -0.57594 & -0.35117 \\
\hline
\end{tabular}

Note: WAB, Brule Harbour; WAT, Waterside; PJO, Port Joli; PRB, Petite Rivière Bridge; DGB, Digby; SP, Starr's Point; NB, Noel Bay; PC, Pecks Cove; MP, Mary's Point; SBC, Strawberry Cove; BAM, Beach Avenue; BOS, Boston; DUX, Duxbury; SHM, Stage Harbour; STO, Stonington. Sampling sites, number of individuals sequenced $(n)$, number of segregating sites $(S)$, number of haplotypes $(H)$, haplotype diversity $(h)$, nucleotide diversity $(\pi)$, and neutrality tests (Fu and Li's $F$ and Tajima's $D$ ). Neutrality tests significantly different from 0 $(P<0.05)$ are indicated by an asterisk $\left(^{*}\right)$.

We amplified a fragment of the cytochrome c oxidase subunit I (COI) mitochondrial gene from both species using the polymerase chain reaction (PCR) primers LCO1490 and HCO2198 (Folmer et al. 1994) (T. obsoleta: GenBank accession no. KY050383-KY050586; Macoma balthica: GenBank accession no. KY061186-KY061198; M. petalum: GenBank accession no. KY049995-KY050188). As M. petalum belongs to a species complex and is sympatric with two distinct lineages of $M$. balthica in the northwestern Atlantic (Meehan 1985; Nikula et al. 2007; Layton et al. 2015), we also amplified a fragment of the COIII gene using the primers MaCO3F and MaCO3R (Nikula et al. 2007) for species identification (GenBank accession no. KY050189-KY050382). Amplification was performed in a $20 \mu \mathrm{L}$ volume consisting of $10 \mathrm{ng}$ DNA, $1 \times$ ThermoPol reaction buffer (New England Biolabs (NEB)), $0.2 \mathrm{mM}$ dNTPs (NEB), $2.5 \mathrm{mM} \mathrm{MgSO}_{4}, 0.5 \mu \mathrm{M}$ forward and reverse primers, and $0.8 \mathrm{U}$ Taq polymerase (NEB). Thermal cycling conditions were $95^{\circ} \mathrm{C}$ for $3 \mathrm{~min}$, followed by 34 cycles of $95^{\circ} \mathrm{C}(30 \mathrm{~s}), 45^{\circ} \mathrm{C}(45 \mathrm{~s}), 72^{\circ} \mathrm{C}(60 \mathrm{~s})$, and a final extension at $72{ }^{\circ} \mathrm{C}$ for $60 \mathrm{~s}$. Amplicons were checked in $1.5 \%$ agarose and sequenced on an ABI $3730 \times 1$ DNA Analyzer using forward, reverse, or both primers at the McGill University and Génome Québec Innovation Centre, Montréal, Canada. 
Table 2. Mitochondrial DNA (COI/COIII) diversity for Macoma petalum populations surveyed.

\begin{tabular}{|c|c|c|c|c|c|c|c|c|}
\hline & Degrees latitude & $n$ & $S$ & $H$ & $h$ & $\pi$ & Tajima's $D$ & Fu and Li's $F$ \\
\hline St. Lawrence & & 41 & 18 & 15 & 0.79024 & 0.00264 & $-1.81352^{\star}$ & $-2.7037^{\star}$ \\
\hline PAP & $48^{\circ} 30^{\prime} 28.46^{\prime \prime}$ & 10 & 7 & 6 & 0.88889 & 0.0035 & 0.37099 & -0.11034 \\
\hline HRC & $47^{\circ} 1^{\prime} 1.94^{\prime \prime}$ & 16 & 10 & 7 & 0.79167 & 0.00268 & -1.39883 & -1.09805 \\
\hline LBR & $45^{\circ} 40^{\prime} 9.32^{\prime \prime}$ & 14 & 6 & 7 & 0.65714 & 0.00176 & -1.15191 & -0.90767 \\
\hline Eastern Nova Scotia & & 42 & 23 & 12 & 0.49361 & 0.00168 & $-2.59226^{*}$ & $-4.84497^{\star}$ \\
\hline CLA & $44^{\circ} 43^{\prime} 59.63^{\prime \prime}$ & 12 & 16 & 5 & 0.66667 & 0.00418 & $-1.92226^{*}$ & $-2.38677^{\star}$ \\
\hline WHY & $44^{\circ} 39^{\prime} 56.82^{\prime \prime}$ & 15 & 5 & 6 & 0.57143 & 0.00095 & $-1.91084^{*}$ & $-2.67082^{\star}$ \\
\hline DGB & $44^{\circ} 35^{\prime} 6.27^{\prime \prime}$ & 15 & 2 & 3 & 0.25714 & 0.00038 & -1.49051 & -2.0195 \\
\hline Bay of Fundy & & 47 & 23 & 8 & 0.27845 & 0.00168 & $-2.24097^{\star}$ & $-3.3625^{\star}$ \\
\hline $\mathrm{MN}$ & $45^{\circ} 46^{\prime} 17.16^{\prime \prime}$ & 13 & 9 & 4 & 0.42308 & 0.00251 & -1.53624 & -1.53207 \\
\hline GA & $45^{\circ} 49^{\prime} 8.64^{\prime \prime}$ & 14 & 2 & 2 & 0.14286 & 0.00041 & -1.48074 & -1.97405 \\
\hline DF & $45^{\circ} 47^{\prime} 1.66^{\prime \prime}$ & 20 & 19 & 4 & 0.28421 & 0.00356 & $-2.01273^{\star}$ & $-2.60112^{*}$ \\
\hline Gulf of Maine & & 64 & 47 & 36 & 0.92907 & 0.00921 & -1.1572 & $-2.45245^{\star}$ \\
\hline LBS & $44^{\circ} 48^{\prime} 47.17^{\prime \prime}$ & 20 & 29 & 14 & 0.93158 & 0.00885 & -0.92947 & -0.69725 \\
\hline MAC & $44^{\circ} 42^{\prime} 33.50^{\prime \prime}$ & 5 & 18 & 4 & 0.9 & 0.01023 & $-1.22752^{\star}$ & -1.31267 \\
\hline AUD & $43^{\circ} 42^{\prime} 37.40^{\prime \prime}$ & 14 & 23 & 10 & 0.94505 & 0.01051 & 0.09528 & 0.16293 \\
\hline FAL & $43^{\circ} 43^{\prime} 9.01^{\prime \prime}$ & 12 & 27 & 11 & 0.98485 & 0.01126 & -0.50872 & -0.04861 \\
\hline BAM & $43^{\circ} 26^{\prime} 16.58^{\prime \prime}$ & 13 & 25 & 10 & 0.92308 & 0.00688 & $-1.72999^{*}$ & -1.93609 \\
\hline Total & & 194 & 64 & 61 & 0.87661 & 0.01088 & -0.94666 & $-3.84682^{\star}$ \\
\hline
\end{tabular}

Note: PAP, Pointe-au-Père; HRC, Black River; LBR, Barneys River; CLA, Clam Harbour; WHY, Whynachts Point; DGB, Digby; MN, Minudie; GA, Grande Anse; DF, Daniels Flat; LBS, Lubec; MAC, Machiasport; AUD, Audubon; FAL, Falmouth; BAM, Beach Avenue. Sampling sites, number of individuals sequenced $(n)$, number of segregating sites $(S)$, number of haplotypes $(H)$, haplotype diversity $(h)$, nucleotide diversity $(\pi)$, and neutrality tests (Fu and Li's $F$ and Tajima's $D)$. Neutrality tests significantly different from $0(P<0.05)$ are indicated by an asterisk $\left({ }^{*}\right)$.

\section{Polymorphism and phylogenetic analyses}

Sequences were edited, aligned, and trimmed to standard lengths in SEQUENCHER, version 5.0 (Gene Codes). To determine whether our Macoma specimens were M. petalum or the morphologically similar species $M$. balthica, we aligned our COIII sequences to published data from Nikula et al. (2007) (GenBank accession no. EF044063-EF044124) and our COI sequences to published data from Layton et al. (2015) (GenBank accession no. KF643258-KP977968). Macoma petalum COI and COIII sequences were concatenated to a $704 \mathrm{bp}$ fragment from each individual for all further analyses. We collapsed mitochondrial sequences into haplotypes and mapped them into separate haplotype networks for each species using statistical parsimony implemented in TCS v.1.21 (Clement et al. 2000) and presented using PopART (http://popart.otago.ac.nz). We calculated standard measurements of nucleotide diversity $(\pi)$, number of segregating sites $(S)$, number of haplotypes $(H)$, and haplotype diversity $(h)$ for each population and region using DNASP v.5.1 (Librado and Rozas 2009). We tested for departures from neutrality based on allelic states or segregating sites with Fu and Li's $F$ (Fu and Li 1993; Simonsen et al. 1995) and Tajima's D (Tajima 1989), respectively, using ARLEQUIN (Excoffier and Lischer 2010). Significance was assessed by 10000 bootstrap replicates. 
For neutral or near-neutral evolving markers such as mtDNA, significantly negative values of these tests can indicate population expansion (Ramos-Onsins and Rozas 2002).

\section{Population differentiation and structure}

To assess the degree to which populations are subdivided both within and between major biogeographic regions in the northwest Atlantic, we calculated global $F_{\mathrm{ST}}$ and tested for pairwise genetic differences between populations $\left(F_{\mathrm{ST}}\right)$ using Kimura two-parameter (Kimura 1980) distances in ARLEQUIN. We tested for genetic subdivision across prominent biogeographic breaks (Fig. 1) using indices of differentiation $(\Phi)$ in a hierarchical analysis of molecular variance (AMOVA) using Kimura two-parameter distances implemented in ARLEQUIN. Significance was assessed using 50000 permutations of the data. The boundaries of our a priori designations of population groupings correspond to strongly diverging currents or persistent gyres hypothesized to cause larval retention within the water masses at Cape Cod (T. obsoleta only), the Bay of Fundy, and the GSL (Hannah et al. 2001; Pettigrew et al. 2005; Aretxabaleta et al. 2008). As the exact location of the break at the Bay of Fundy is unknown (see Einfeldt and Addison 2013), samples of both species collected from Digby (DGB), Nova Scotia (Fig. 1) were independently assigned to regional groupings based on the significance of pairwise comparisons among populations from adjacent regions.

We tested for isolation by distance (IBD) within, between, and across regions using Mantel tests (Wright 1943) implemented in the isolation by distance web service (IBDWS) (Jensen et al. 2005), with significance assessed over 10000 permutations. Pairwise genetic distance was measured as $F_{\mathrm{ST}}$ and geographic distances were measured as the log of shortest marine path between GPS site coordinates of each population. As tests of the correlation between genetic and geographic distance can be biased by spatial autocorrelation in the presence of hierarchical population structure (Meirmans 2012), we separately tested pairwise comparisons among populations within each distinct region.

\section{Results}

\section{Diversity and polymorphism}

We obtained a $467 \mathrm{bp}$ alignment of COI from 204 samples of T. obsoleta that contained 30 unique haplotypes with 27 variable sites (Table 1). Analysis using statistical parsimony resulted in several unresolved loops, and the two most divergent haplotypes were separated by 12 mutations (Fig. $2 a$ ). There were 15 singleton mutations and 10 unique haplotypes that were shared in populations from at least two different geographic regions. Calculations of Fu and Li's F (Fu and Li 1993) and Tajima's $D$ (Tajima 1989) failed to detect significant departures from neutrality over all populations (Table 1), and the only negative value of $F$ that was significant $(F=-2.5271, P<0.05)$ was found in the Bay of Fundy region. Tajima's $D$ was significantly greater than zero in the Nova Scotia populations, indicating an excess of low- and high-frequency alleles resulting from either a population contraction or balancing selection. Diversity indices $\pi$ and $h$ generally declined with increasing distance from the southernmost population (Table 1 ), suggesting that $T$. obsoleta likely persisted in southern refugia during the last glacial maxima and then colonized northwards to establish its current range.

We detected 13 individuals of $M$. balthica in the GSL based on the alignment of COIII sequences to data presented in Nikula et al. (2007) and COI sequences to data presented in Layton et al. (2015). The remaining 194 samples of $M$. petalum show 61 unique haplotypes from concatenated sequences of COI (345 bp) and COIII (359 bp) with 64 total variable sites (Table 2). The statistical parsimony network indicates two clusters of haplotypes representing two unique lineages separated by 10 mutations that correspond to the $M$. petalum lineages a1 (our more diverse lineage) and a2 (our less diverse lineage, found mostly in eastern Nova Scotia and the Gulf of Maine; Fig. $2 b$ ) identified by Nikula et al. (2007). The mean Kimura two-parameter distance between these lineages is $1.8 \%$ at $\mathrm{COI}$ and $2.6 \%$ at 
(a)

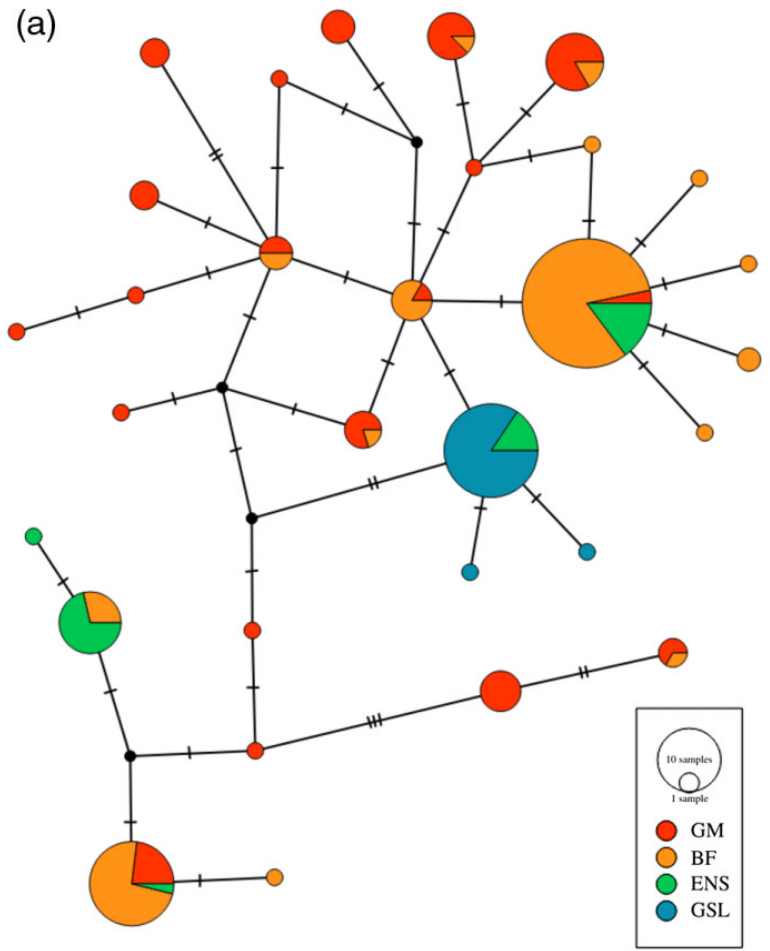

(b)

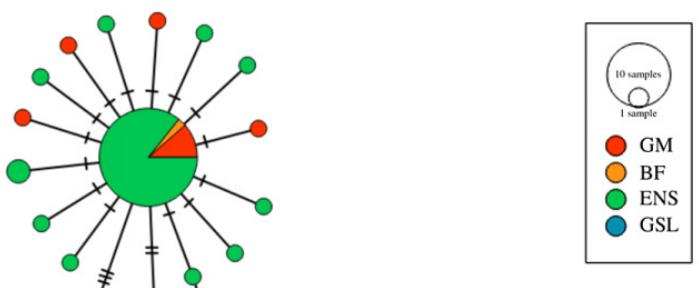

Fig. 2. (a) TCS haplotype network for COI mitochondrial DNA (mtDNA) for Tritia obsoleta. Circle area is proportional to the number of haplotypes sequenced. (b) TCS haplotype network for concatenated COI/COIII mtDNA for Macoma petalum. Circle area is proportional to the number of haplotypes sequenced. The more diverse and less diverse lineages correspond respectively to lineages a1 and a2 from Nikula et al. (2007).

COIII. These values are below the $3 \%$ threshold typically used for species delimitation using COI (Hebert et al. 2003), and the more extensive interspecific phylogenies presented by Nikula et al. (2007) and Layton et al. (2015) indicate that the divergent lineages of M. petalum represent past population fragmentation (0.4-0.7 Mya) and are unlikely to be reproductively isolated cryptic species. Following Nikula et al. (2007) and Layton et al. (2015), we thus included both M. petalum lineages as a single species in our analyses.

The distinctly "star-like" distribution of unique haplotypes surrounding two of the three most common haplotypes of both lineages (Fig. $2 b$ ) is indicative of range or population expansion (Rogers and Harpending 1992) in the Gulf of Maine, eastern Nova Scotia, and the GSL. This hypothesis is supported by significantly negative values of Fu and Li's F (Fu and Li 1993) in all regions, and significantly negative Tajima's $D$ (Tajima 1989) in all regions except the Gulf of Maine (Table 2). However, although negative values indicate an excess of low-frequency mutations resulting from population expansion, similar patterns are also expected under a model of purifying selection. Diversity indices $\pi$ and $h$ were notably lower in the Bay of Fundy than in other regions.

\section{Population differentiation and structure}

Global $F_{\mathrm{ST}}$ values indicate a strong and significant variance in the distribution of genetic variation among populations of both species ( $T$. obsoleta: $F_{\mathrm{ST}}=0.2493, P<0.05 ;$ M. petalum: $F_{\mathrm{ST}}=0.6016$, $P<0.05)$. Pairwise genetic differences $\left(F_{\mathrm{ST}}\right)$ between populations of $T$. obsoleta showed significant genetic differentiation in three of $27(11 \%)$ comparisons within regions, and 70 of the $78(88 \%)$ 
Table 3. Pairwise $F_{\mathrm{ST}}$ values among sampling locations for Tritia obsoleta using mitochondrial DNA (COI).

\begin{tabular}{|c|c|c|c|c|c|c|c|c|c|c|c|c|c|c|c|}
\hline & WAB & WAT & PRB & PJO & DGB & SP & NB & PC & MP & SBC & BAM & BOS & DUX & SHM & STO \\
\hline WAB & - & - & + & + & + & + & + & + & + & + & + & + & + & + & + \\
\hline WAT & 0.00493 & - & + & + & + & + & + & + & + & + & + & + & + & + & + \\
\hline PRB & 0.64668 & 0.56106 & - & + & + & + & + & + & + & + & + & + & + & + & + \\
\hline PJO & 0.76650 & 0.74036 & 0.64060 & - & + & + & + & + & + & + & + & + & + & + & + \\
\hline DGB & 0.53614 & 0.50572 & 0.11352 & 0.39142 & - & - & - & - & - & + & + & + & + & + & + \\
\hline SP & 0.51421 & 0.48580 & 0.10936 & 0.42192 & -0.04620 & - & - & - & - & + & + & - & + & + & + \\
\hline $\mathrm{NB}$ & 0.40732 & 0.38547 & 0.13275 & 0.30886 & -0.01682 & -0.02032 & - & - & - & + & - & - & + & - & - \\
\hline $\mathrm{PC}$ & 0.57977 & 0.55045 & 0.11441 & 0.47334 & -0.04911 & -0.03901 & 0.01683 & - & - & + & + & + & + & + & + \\
\hline MP & 0.48164 & 0.45897 & 0.20250 & 0.29405 & -0.00490 & -0.00823 & -0.03414 & 0.03421 & - & + & - & - & + & - & + \\
\hline SBC & 0.49370 & 0.45269 & 0.37426 & 0.37273 & 0.25835 & 0.25830 & 0.13781 & 0.33419 & 0.21004 & - & - & - & - & - & - \\
\hline BAM & 0.57821 & 0.52386 & 0.37519 & 0.34595 & 0.19112 & 0.19040 & 0.04683 & 0.28201 & 0.11970 & -0.10262 & - & - & - & - & - \\
\hline BOS & 0.46144 & 0.42374 & 0.27521 & 0.32633 & 0.13045 & 0.11495 & 0.04252 & 0.19745 & 0.05281 & 0.07027 & -0.00153 & - & - & - & - \\
\hline DUX & 0.69862 & 0.64413 & 0.46062 & 0.54865 & 0.30107 & 0.29570 & 0.16792 & 0.37638 & 0.26760 & 0.07134 & -0.01533 & 0.12994 & - & + & + \\
\hline SHM & 0.28523 & 0.25966 & 0.16122 & 0.28465 & 0.09781 & 0.10067 & 0.03278 & 0.15497 & 0.06551 & 0.03883 & -0.02588 & -0.01112 & 0.11715 & - & - \\
\hline STO & 0.52860 & 0.48041 & 0.36733 & 0.33086 & 0.21750 & 0.21523 & 0.11232 & 0.29608 & 0.14038 & 0.06140 & -0.02958 & 0.03956 & 0.22833 & -0.02808 & - \\
\hline
\end{tabular}

Note: WAB, Brule Harbour; WAT, Waterside; PRB, Petite Rivière Bridge; PJO, Port Joli; DGB, Digby; SP, Starr's Point; NB, Noel Bay; PC, Pecks Cove; MP, Mary's Point; SBC, Strawberry Cove; BAM, Beach Avenue; BOS, Boston; DUX, Duxbury; SHM, Stage Harbour; STO, Stonington. Values of $F_{\mathrm{ST}}$ are the diagonal with significant values in bold, and significance ("+ " for $P<0.05$, “-” for $P>0.05$ ) is indicated above the diagonal. - indicates no data.

comparisons between regions (Table 3). Pairwise $F_{\mathrm{ST}}$ between populations at Cape Cod (Stonington (STO), Stage Harbour (SHM); Fig. 1) and the rest of the Gulf of Maine were only significant when compared with Duxbury (DUX) (STO-DUX: $F_{\mathrm{ST}}=0.2283, P<0.05$; SHM-DUX: $F_{\mathrm{ST}}=0.1172$, $P<0.05)$. Therefore, we included these populations in the Gulf of Maine regional grouping. For M. petalum, only three of 19 pairwise comparisons (16\%) within regions showed significant differentiation, in contrast to 64 of 72 comparisons (89\%) between regions (Table 4). These patterns suggest that dispersal with gene flow is high within each of the regions, but greatly reduced among them. Pairwise comparisons of the DGB population showed notably different patterns for each species; for T. obsoleta DGB was significantly different from all populations except those in the Bay of Fundy, whereas for M. petalum DGB was significantly different from all populations except Whynachts Point (WHY) in the Atlantic coast of Nova Scotia (see Fig. 1).

Hierarchical analysis of population structure between regions defined a priori by circulation patterns (Gulf of St. Lawrence = GSL; Eastern Nova Scotia = ENS; Bay of Fundy = BOF; Gulf of Maine = GOM) indicated significant genetic subdivision among all four regions for both species (T. obsoleta: $\Phi_{\mathrm{CT}}=0.2020, P<0.001 ;$ M. petalum: $\Phi_{\mathrm{CT}}=0.654, P<0.001$; Table 5). We detected concordant subdivision between the Gulf of Maine and the Bay of Fundy for both species (T. obsoleta: $\Phi_{\mathrm{CT}}=$ $0.144, P=0.002$; $M$. petalum: $\Phi_{\mathrm{CT}}=0.329, P=0.018$ ). In addition, we detected subdivision between the Gulf of Maine and eastern Nova Scotia for $M$. petalum $\left(\Phi_{\mathrm{CT}}=0.670, P=0.018\right)$ but not for T. obsoleta, and no significant values of $\Phi_{\mathrm{CT}}$ between the GSL and ENS or between ENS and $\mathrm{BF}$ for either species. However, our pairwise comparisons including either the ENS or GSL may be biased by the low number of populations in these regions ( . obsoleta, $n=2$; M. petalum, $n=3$ ), 
Table 4. Pairwise $F_{\mathrm{ST}}$ values among sampling locations for Macoma petalum using mitochondrial DNA (COI/COIII).

\begin{tabular}{|c|c|c|c|c|c|c|c|c|c|c|c|c|c|c|}
\hline & PAP & HRC & LBR & CLA & WHY & DGB & MN & GA & DF & LBS & MAC & AUD & FAL & BAM \\
\hline PAP & - & - & + & + & + & + & + & + & + & - & - & + & + & - \\
\hline HRC & 0.04044 & - & - & + & + & + & + & + & + & - & - & + & + & - \\
\hline LBR & 0.13456 & 0.01857 & - & + & + & + & + & + & + & - & - & + & + & + \\
\hline CLA & 0.81011 & 0.82700 & 0.85353 & - & + & + & + & + & + & + & + & + & + & + \\
\hline WHY & 0.91392 & 0.91330 & 0.93694 & 0.02932 & - & - & + & + & + & + & + & + & + & + \\
\hline DGB & 0.92875 & 0.92519 & 0.94951 & 0.03543 & -0.00005 & - & + & + & + & + & + & + & + & + \\
\hline $\mathrm{MN}$ & 0.29627 & 0.45160 & 0.59241 & 0.83654 & 0.92421 & 0.93716 & - & - & - & + & + & + & + & + \\
\hline GA & 0.57018 & 0.66892 & 0.79676 & 0.89495 & 0.96933 & 0.98225 & 0.04129 & - & - & + & + & + & + & + \\
\hline $\mathrm{DF}$ & 0.27366 & 0.41363 & 0.53272 & 0.80252 & 0.88312 & 0.89321 & -0.04021 & 0.01424 & - & + & + & + & + & + \\
\hline LBS & 0.04369 & 0.04062 & 0.08071 & 0.60251 & 0.71442 & 0.72344 & 0.24835 & 0.37626 & 0.25135 & - & - & - & - & - \\
\hline MAC & 0.03757 & 0.06775 & 0.14661 & 0.62300 & 0.80831 & 0.83179 & 0.30704 & 0.54101 & 0.27499 & -0.10393 & - & - & - & - \\
\hline AUD & 0.16584 & 0.15924 & 0.21053 & 0.53845 & 0.67624 & 0.68778 & 0.34337 & 0.47700 & 0.34527 & 0.00686 & -0.05555 & - & - & - \\
\hline FAL & 0.15181 & 0.14503 & 0.19316 & 0.56485 & 0.70164 & 0.71378 & 0.33778 & 0.47947 & 0.34649 & 0.01044 & -0.04923 & -0.06173 & - & - \\
\hline BAM & 0.02179 & 0.00401 & 0.04294 & 0.69647 & 0.81315 & 0.82589 & 0.32720 & 0.50271 & 0.32520 & -0.03452 & -0.08165 & 0.01520 & 0.00410 & - \\
\hline
\end{tabular}

Note: PAP, Pointe-au-Père; HRC, Black River; LBR, Barneys River; CLA, Clam Harbour; WHY, Whynachts Point; DGB, Digby; MN, Minudie; GA, Grande Anse; DF, Daniels Flat; LBS, Lubec; MAC, Machiasport; AUD, Audubon; FAL, Falmouth; BAM, Beach Avenue. Values of $F_{\text {ST }}$ are below the diagonal with significant values in bold, and significance ("+" for $P<0.05$, "-" for $P>0.05$ ) is indicated above the diagonal. — indicates no data.

Table 5. Analysis of molecular variance results for regions structured according to circulation patterns using mitochondrial DNA from Tritia obsoleta (COI) and Macoma petalum (COI/COIII).

\begin{tabular}{lllllll} 
& $\boldsymbol{\Phi}_{\mathrm{SC}}$ & $\boldsymbol{\Phi}_{\mathrm{ST}}$ & $\boldsymbol{\Phi}_{\mathrm{CT}}$ & $\boldsymbol{\Phi}_{\mathrm{SC}} \boldsymbol{P}$ & $\boldsymbol{\Phi}_{\mathrm{ST}} \boldsymbol{P}$ & $\boldsymbol{\Phi}_{\mathrm{CT}} \boldsymbol{P}$ \\
\hline Tritia obsoleta & & & & & & \\
\hline GSL/ENS & $\mathbf{0 . 6 2 0 6 4}$ & $\mathbf{0 . 7 3 3 0 7}$ & 0.29637 & 0.00006 & $<0.0001$ & 0.33343 \\
\hline ENS/BF & $\mathbf{0 . 1 3 9}$ & $\mathbf{0 . 1 8 3 7 3}$ & 0.05196 & 0.00082 & 0.00002 & 0.19163 \\
\hline ENS/GM & $\mathbf{0 . 1 8 9 2 9}$ & $\mathbf{0 . 2 4 5 3 4}$ & 0.06914 & 0.00008 & $<0.0001$ & 0.2158 \\
\hline BF/GM & 0.01781 & $\mathbf{0 . 1 5 8 8 7}$ & $\mathbf{0 . 1 4 3 6 2}$ & 0.27823 & 0.00008 & 0.00249 \\
\hline GSL/ENS/BF/GM & $\mathbf{0 . 1 0 8 4 8}$ & $\mathbf{0 . 2 8 8 5 6}$ & $\mathbf{0 . 2 0 2}$ & $<0.0001$ & 0.00076 & 0.00004 \\
\hline Macoma petalum & & & & & & \\
\hline GSL/ENS & $\mathbf{0 . 0 4 5 7 8}$ & $\mathbf{0 . 9 0 0 5 3}$ & 0.89575 & 0.02176 & $<0.0001$ & 0.09812 \\
\hline ENS/BF & 0.00578 & $\mathbf{0 . 9 0 3 8 1}$ & 0.90325 & 0.27269 & $<0.0001$ & 0.10085 \\
\hline ENS/GM & -0.01033 & $\mathbf{0 . 6 6 7}$ & $\mathbf{0 . 6 7 0 4}$ & 0.65654 & $<0.0001$ & 0.01812 \\
\hline BF/GM & -0.01143 & $\mathbf{0 . 3 2 1 3 1}$ & $\mathbf{0 . 3 2 8 9 8}$ & 0.71318 & $<0.0001$ & 0.01766 \\
\hline GSL/ENS/BF/GM & 0.00133 & $\mathbf{0 . 6 5 4 2 4}$ & $\mathbf{0 . 6 5 3 7 8}$ & 0.54732 & $<0.0001$ & $<0.0001$ \\
\hline
\end{tabular}

Note: GSL, Gulf of St. Lawrence; ENS, eastern Nova Scotia; BF, Bay of Fundy; GM, Gulf of Maine. Significant values of $\Phi_{\mathrm{SC}}, \Phi_{\mathrm{ST}}$, and $\Phi_{\mathrm{CT}}(P<0.05)$ are in bold. 
Table 6. Isolation by distance results from the isolation by distance web service.

Data set Spearman's rank correlation index $(r) \quad P$-value $\quad$ Linear regression coefficient $\left(R^{2}\right)$

Tritia obsoleta COI

\begin{tabular}{lccl} 
Over range & $\mathbf{0 . 6 3 2 3}$ & $<0.001$ & 0.4 \\
\hline GM & -0.1159 & 0.616 & 0.0134 \\
BF & -0.4066 & 0.842 & 0.165 \\
\hline Macoma petalum COI/COIII & & & \\
Over range & 0.1897 & 0.067 & 0.036 \\
\hline GM & -0.5273 & 0.736 & 0.0607 \\
BF & 0.6023 & 0.169 & 0.363 \\
\hline ENS & 0.8308 & 0.176 & 0.69 \\
\hline GSL & 0.9235 & 0.166 & 0.853 \\
\hline
\end{tabular}

Note: GM, Gulf of Maine; BF, Bay of Fundy; GSL, Gulf of St. Lawrence; ENS, Eastern Nova Scotia. $P$-values for Mantel tests of correlation between $F_{\mathrm{ST}}$ for mtDNA and log geographic distance. Significant values of $r$ are in bold.

and must thus be interpreted cautiously. As overall hierarchical structure was significant, we stress that the absence of significant genetic differentiation between adjacent regions does not provide strong evidence for a lack of divergence between them.

The Mantel tests provided moderate evidence for a nonrandom association between geographical distance and genetic differentiation among all populations of T. obsoleta $\left(R^{2}=0.400, P<0.001\right)$, but not M. petalum $\left(R^{2}=0.036, P<0.067\right)$ (Table 6). Similar comparisons among populations within each region failed to detect IBD for either species; however, we were unable to evaluate whether IBD contributed to genetic patterns in T. obsoleta from the GSL and SS because we only sampled two populations in each of these regions.

\section{Discussion}

Comparison of phylogeographic patterns in multiple codistributed species is a powerful way to reveal shared evolutionary history such as dispersal limitation across biogeographic barriers (e.g., Bowen et al. 2014). We detected significant population genetic structure in both T. obsoleta and M. petalum with a concordant break that isolates the Bay of Fundy from the Gulf of Maine, and a divergent lineage of M. petalum present only in eastern Nova Scotia and the Gulf of Maine. Sample sites within regions were genetically homogeneous and lacked IBD, indicating high dispersal with gene flow at local scales. In contrast to the complete absence of gene flow between the Gulf of Maine and Bay of Fundy observed in $C$. volutator and $H$. diversicolor, we detected shared genetic variation between regions in both T. obsoleta and M. petalum. However, haplotype frequencies changed rapidly at the mouth of the Bay of Fundy, and we interpret this pattern as a result of limited ongoing gene flow across the break, and the accumulation of differences between regions as a result of random genetic drift. Our results are consistent with the phylogeographic break observed in other species that lack pelagic larval dispersal (Einfeldt and Addison 2013; Einfeldt et al. 2014), and suggest that the strong gyre separating the Bay of Fundy from the Gulf of Maine is a potent barrier to dispersal, which isolates biota in the inner Bay of Fundy from the Atlantic Ocean.

Biogeographic breaks are defined by the concordant geographical distributions of many species (Briggs 1974) and are strongly linked to a combination of physical boundaries and strong 
environmental gradients (Gaylord and Gaines 2000; Altman et al. 2013; Bowen et al. 2014; Pappalardo et al. 2015). Our study suggests that the gyre at the mouth of the Bay of Fundy significantly limits connectivity among the regions, but the boundaries across this transition zone are unclear. Patterns of genetic structure in C. volutator (Einfeldt and Addison 2013) indicate that populations near the mouth of the Bay show an admixture of haplotypes from strongly divergent populations in the inner Bay of Fundy and the Gulf of Maine. We compared our M. petalum COI sequences with published data in Layton et al. (2015) and detected a similar pattern of admixture (of both a1 and a2 lineages) in samples from Saint Andrew's, along the western shore of new Brunswick near the mouth of the Bay of Fundy (Supplementary Material 1). In addition, samples of C. volutator from DGB clustered with samples from the Gulf of Maine (Einfeldt and Addison 2013), but in our collections from DGB, T. obsoleta was genetically identical to the Bay of Fundy, whereas M. petalum was genetically more similar to samples from eastern Nova Scotia. Population genetic studies in other species also show mixed patterns across this transition zone (e.g., Gartner-Kepkay et al. 1980; Dillon and Manzi 1992; Addison and Hart 2004; Evans et al. 2004; Kelly et al. 2006; Kenchington et al. 2006; Jennings et al. 2009; So et al. 2011; Owen and Rawson 2013; St-Onge et al. 2013; Benestan et al. 2015; Govindarajan et al. 2015), but as these studies only sampled one population in or at the mouth of the bay, they provide little resolution to the boundaries of phylogeographic transition. Although many species of marine invertebrates sampled in the Bay of Fundy appear isolated from populations studied elsewhere, incongruence in the location of the break suggests that the physical boundaries to gene flow across the gyre depend on a variety of factors including both dispersal ability and evolutionary history.

Broader phylogeographic patterns of subdivision between the Gulf of Maine, eastern Nova Scotia, and the GSL are generally consistent with previous studies of intertidal (Dillon and Manzi 1992; Kelly et al. 2006; Baker et al. 2008) and subtidal species (Kenchington et al. 2006; St-Onge et al. 2013; Benestan et al. 2015). Although the AMOVA results indicated strong regional differentiation for both species, levels of intraspecific genetic variation differed substantially between the species. Samples of T. obsoleta collected in the GSL had the lowest levels of haplotype $(h)$ and nucleotide $(\pi)$ diversity compared to populations sampled further to the south. Both IBD and a decrease in genetic diversity with latitude suggest that low diversity in the GSL populations may be a result of either post-glacial population expansion (Hewitt 1999; Marko 2004) or increased genetic drift at lower and (or) more variable population abundance at the range periphery (Lawton 1993; Vucetich and Waite 2003; Provan and Maggs 2012). In contrast, populations of $M$. petalum from the GSL were characterized as having relatively high levels of genetic diversity and formed mixed aggregations with its sister species $M$. balthica (see Layton et al. 2015). Geographical range limits result from interplay between abiotic and interspecific interactions, but simulations suggest that in zones of sympatry both species will have reduced population sizes and genetic diversity (Case and Taper 2000). However, spatial overlap between the two species can result in the evolution of local intraspecific character displacement or disruptive selection, which can lead to an increase in genetic variation (Rueffler et al. 2006). Future studies of both T. obsoleta and M. petalum should aim to use additional markers (i.e., nuclear loci) to understand the factors driving patterns of genetic diversity at the range limits, and continue to monitor changes in these populations as climate change continues to impact coastal marine systems.

Despite the ecological differences between the Bay of Fundy and the Gulf of Maine, there is currently only limited evidence that natural selection is a driving factor that shapes patterns of genetic differentiation across this region. The Bay of Fundy is a unique ecosystem characterized by expansive mudflats subject to high-energy tidal fluctuation and severe abiotic stresses such as ice cover, ice scour, and low winter temperatures (Partridge 2001; Drolet et al. 2013; Gerwing et al. 2015). Population densities of some marine invertebrates are significantly impacted by winter stressors (Gerwing et al. 2015), and there is substantial among-mudflat variability in the frequency and duration of population 
crashes in some species (Cranford et al. 1985; Coulthard and Hamilton 2011). Adult M. petalum are less actively mobile than T. obsoleta, and may thus be more susceptible to dramatic fluctuations in population size, which cause genetic bottlenecks or selective sweeps and reduce levels of genetic diversity. Consistent with this prediction, genetic diversity was lowest for M. petalum in the Bay of Fundy and highest in the Gulf of Maine, and significant negative values of Tajima's $D$ (Tajima 1989) and Fu and Li's $F$ (Fu and Li 1993) suggest either population expansion or purifying selection in the Bay of Fundy and elsewhere. However, as mtDNA is putatively a neutral genetic marker, we are currently unable to assess the role of natural selection in driving patterns of genetic diversity in T. obsoleta or M. petalum.

Although strong environmental gradients exist in the northwest Atlantic, including the Bay of Fundy, biogeographic studies suggest that natural selection alone may not be responsible for defining the range limits and community assemblages of many marine invertebrates. In a review of 1770 species, Pappalardo et al. (2015) demonstrated that the mouth of the Bay of Fundy was the northern range limit for approximately $50 \%$ of the shallow water species $(<20 \mathrm{~m})$ surveyed. However, comparison of the minimum thermal tolerance of these species with minimum historical water temperature observations did not produce a good match to the species boundaries. Instead, peaks in range limits were better correlated with oceanographic features that retained larvae or reduced alongshore transport. Although range boundaries are fundamentally set by environmental tolerances (Sunday et al. 2012), the exact location of the split for each species is strongly influenced by dispersal limitation (Pappalardo et al. 2015). Though strong environmental gradients have been detected throughout the Gulf of Maine and the Bay of Fundy, ecological differences are unlikely to be the primary driver of range limits among species and intraspecific divergence within lineages.

As many species are responding to increasing ocean temperatures by shifting their ranges (Helmuth et al. 2006; Sunday et al. 2012; Deutsch et al. 2015), identifying boundaries of concordant inter- and intraspecific changes will help identify the regions in which the impacts of climate change and anthropogenic disturbance are the greatest. The mouth of the Bay of Fundy is a recognized biogeographic break (Wilkinson et al. 2009; Pappalardo et al. 2015), and our research indicates that this is also a phylogeographic transition zone. Conservation and management plans aimed at protecting environmental and economic interests throughout this region will benefit from additional genetic studies of a variety of marine species. Exploring the genetic discontinuities across this boundary in multiple species with greater spatial and genomic sampling will provide much greater understanding of how near-shore currents and environmental transitions limit or promote larval dispersal, identifying ecologically relevant connections between populations (Palumbi 2003). This information will help predict the local and regional responses to climate change, anthropogenic disturbance, and the spread of invasive species.

\section{Acknowledgements}

We thank A. Joyce, V. Baba, and A. MacEacheron for assistance in the lab, and M. Barbeau for assistance in the field. Funding was provided through Natural Science and Engineering Research Council (Discovery), Canadian Foundation for Innovation (Leaders Opportunity Fund), New Brunswick Innovation Foundation, and New Brunswick Wildlife Trust Fund grants to JAA, an NSERC Undergraduate Summer Research Assistantship to FZ, and a UNB Research Assistantship to ALE.

\section{Author contributions}

Conceived and designed the study: ALE, FZ, JAA. Performed the experiments/collected the data: ALE, FZ, JAA. Analyzed and interpreted the data: ALE, FZ, JAA. Contributed resources: JAA. Drafted or revised the manuscript: ALE, FZ, JAA. 


\section{Competing interests}

The authors have declared that no competing interests exist.

\section{Data accessibility statement}

All relevant data are within the paper, the Supplementary Material, and GenBank (www.ncbi.nlm.nih. gov/genbank/; Accession Numbers: KY050383-KY050586, KY061186-KY061198, KY049995KY050188, KY050189-KY050382, EF044063-EF044124, KF643258-KP977968).

\section{Supplementary material}

The following Supplementary Material is available with the article through the journal website at doi:10.1139/facets-2016-0044.

Supplementary Material 1

\section{References}

Addison JA, and Hart MW. 2004. Analysis of population genetic structure of the green sea urchin (Strongylocentrotus droebachiensis) using microsatellites. Marine Biology, 144: 243-251. doi:10.1007/s00227-003-1193-6.

Altman S, Robinson JD, Pringle JM, Byers JE, and Wares JP. 2013. Edges and overlaps in northwest Atlantic phylogeography. Diversity, 5: 263-275. doi:10.3390/d5020263.

Aretxabaleta AL, McGillicuddy DJ, Smith KW, and Lynch DR. 2008. Model simulations of the Bay of Fundy Gyre: 1. Climatological results. Journal of Geophysical Research: Oceans, 113(C10): C10027. doi:10.1029/2007JC004480.

Baker P, Austin JD, Bowen BW, and Baker SM. 2008. Range-wide population structure and history of the northern quahog (Mercenaria mercenaria) inferred from mitochondrial DNA sequence data. ICES Journal of Marine Science, 65: 155-163. doi:10.1093/icesjms/fsn007.

Benestan L, Gosselin T, Perrier C, Sainte-Marie B, Rochette R, and Bernatchez L. 2015. RAD genotyping reveals fine-scale genetic structuring and provides powerful population assignment in a widely distributed marine species, the American lobster (Homarus americanus). Molecular ecology, 24: 3299-3315. PMID:25977167. doi:10.1111/mec.13245.

Bowen B, Shanker K, Yasuda N, Malay M, von der Heyden S, Paulay G, et al. 2014. Phylogeography unplugged: comparative surveys in the genomic era. Bulletin of Marine Science, 90: 13-46. doi:10.5343/bms.2013.1007.

Briggs JC. 1974. Marine zoogeography. McGraw Hill, New York, New York.

Byers JE, and Pringle JM. 2006. Going against the flow: retention, range limits and invasions in advective environments. Marine Ecology Progress Series, 313: 27-41. doi:10.3354/meps313027.

Caddy JF. 1969. Development of mantle organs, feeding, and locomotion in postlarval Macoma balthica (L.) (Lamellibranchiata). Canadian Journal of Zoology, 47: 609-617. doi:10.1139/z69-105.

Case TJ, and Taper ML. 2000. Interspecific competition, environmental gradients, gene flow, and the coevolution of species' borders. The American Naturalist, 155: 583-605. PMID:10777432. doi:10.1086/303351. 
Clement M, Posada DC, and Crandall KA. 2000. TCS: a computer program to estimate gene genealogies. Molecular Ecology, 9: 1657-1659. PMID:11050560. doi:10.1046/j.1365-294x.2000.01020.x.

Coulthard ME, and Hamilton DJ. 2011. Effects of Ilyanassa obsoleta (Say) on the abundance and vertical distribution of Corophium volutator (Pallas) on mudflats of the upper Bay of Fundy. Journal of Experimental Marine Biology and Ecology, 397: 161-172. doi:10.1016/j.jembe.2010.12.001.

Cranford PJ, Peer DL, and Gordon DC. 1985. Population dynamics and production of Macoma balthica in Cumberland Basin and Shepody Bay, Bay of Fundy. Netherlands Journal of Sea Research, 19: 135-146. doi:10.1016/0077-7579(85)90018-3.

Deutsch C, Ferrel A, Seibel B, Pörtner HO, and Huey RB, 2015. Climate change tightens a metabolic constraint on marine habitats. Science, 348: 1132-1135. PMID:26045435. doi:10.1126/science. aaa1605.

Díaz-Ferguson E, Robinson JD, Silliman B, and Wares JP. 2010. Comparative phylogeography of North American Atlantic salt marsh communities. Estuaries and Coasts, 33: 828-839. doi:10.1007/ s12237-009-9220-6.

Dillon RT Jr, and Manzi JJ. 1992. Population genetics of the hard clam, Mercenaria mercenaria, at the northern limit of its range. Canadian Journal of Fisheries and Aquatic Sciences, 49: 2574-2578. doi:10.1139/f92-284.

Doyle JJ, and Doyle JL. 1987. A rapid DNA isolation procedure for small quantities of fresh leaf tissue. Phytochemical Bulletin, 19: 11-15.

Drinkwater K, and Gilbert D. 2004. Hydrographic variability in the waters of the Gulf of St. Lawrence, the Scotian Shelf and the eastern Gulf of Maine (NAFO Subarea 4) during 1991-2000. Journal of Northwest Atlantic Fishery Science, 34: 83-99.

Drolet D, Kennedy K, and Barbeau MA. 2013. Winter population dynamics and survival strategies of the intertidal mudflat amphipod Corophium volutator (Pallas). Journal of Experimental Marine Biology and Ecology, 441: 126-137. doi:10.1016/j.jembe.2013.01.023.

Einfeldt AL, and Addison JA. 2013. Hydrology influences population genetic structure and connectivity of the intertidal amphipod Corophium volutator in the northwest Atlantic. Marine Biology, 160: 1015-1027. doi:10.1007/s00227-012-2154-8.

Einfeldt AL, and Addison JA. 2015. Anthropocene invasion of an ecosystem engineer: resolving the history of Corophium volutator (Amphipoda: Corophiidae) in the North Atlantic. Biological Journal of the Linnean Society, 115: 288-304. doi:10.1111/bij.12507.

Einfeldt AL, Doucet JR, and Addison JA. 2014. Phylogeography and cryptic introduction of the ragworm Hediste diversicolor (Annelida, Nereididae) in the Northwest Atlantic. Invertebrate Biology, 133: 232-241. doi:10.1111/ivb.12060.

Engle VD, and Summers JK. 1999. Latitudinal gradients in benthic community composition in Western Atlantic estuaries. Journal of Biogeography, 26: 1007-1023. doi:10.1046/j.1365-2699. 1999.00341.x.

Evans KM, Bates SS, Medlin LK, and Hayes PK. 2004. Microsatellite marker development and genetic variation in the toxic marine diatom Pseudo-nitzschia multiseries (Bacillariophyceae). Journal of Phycology, 40: 911-920. doi:10.1111/j.1529-8817.2004.04027.x. 
Excoffier L, and Lischer HE. 2010. ARLEQUIN suite ver 3.5: a new series of programs to perform population genetics analyses under Linux and Windows. Molecular Ecology Resources, 10: 564-567. PMID:21565059. doi:10.1111/j.1755-0998.2010.02847.x.

Folmer O, Black M, Hoeh W, Lutz R, and Vrijenhoek R. 1994. DNA primers for amplification of mitochondrial cytochrome $\mathrm{c}$ oxidase subunit I from diverse metazoan invertebrates. Molecular Marine Biology and Biotechnology, 3: 294-299. PMID:7881515.

Fu Y-X, and Li W-H. 1993. Statistical tests of neutrality of mutations. Genetics, 133: 693-709. PMID:8454210.

Galindo LA, Puillandre N, Utge J, Lozouet P, and Bouchet P. 2016. The phylogeny and systematics of the Nassariidae revisited (Gastropoda, Buccinoidea). Molecular Phylogenetics and Evolution, 99: 337-353. PMID:27012605. doi:10.1016/j.ympev.2016.03.019.

Gartner-Kepkay KE, Dickie LM, Freeman KR, and Zouros E. 1980. Genetic differences and environments of mussel populations in the Maritime Provinces. Canadian Journal of Fisheries and Aquatic Sciences, 37: 775-782. doi:10.1139/f80-104.

Gaylord B, and Gaines SD. 2000. Temperature or transport? Range limits in marine species mediated solely by flow. The American Naturalist, 155: 769-789. PMID:10805643. doi:10.1086/303357.

Gerwing TG, Drolet D, Barbeau MA, Hamilton DJ, and Gerwing AM. 2015. Resilience of an intertidal infaunal community to winter stressors. Journal of Sea Research, 97: 40-49. doi:10.1016/j. seares.2015.01.001.

Gooch JL, Smith BS, and Knupp D. 1972. Regional survey of gene frequencies in the mud snail Nassarius obsoletus. The Biological Bulletin, 142: 36-48. doi:10.2307/1540244.

Govindarajan AF, Bukša F, Bockrath K, Wares JP, and Pineda J. 2015. Phylogeographic structure and northward range expansion in the barnacle Chthamalus fragilis. PeerJ, 3: e926. PMID:25945315. doi:10.7717/peerj.926.

Hannah CG, Shore JA, Loder JW, and Naimie CE. 2001. Seasonal circulation on the western and Central Scotian Shelf. Journal of Physical Oceanography, 31: 591-615. doi:10.1175/1520-0485(2001) 031<0591:SCOTWA>2.0.CO;2.

Hale SS. 2010. Biogeographical patterns of marine benthic macroinvertebrates along the Atlantic coast of the northeastern USA. Estuaries and Coasts, 33: 1039-1053. doi:10.1007/s12237-010-9332-z.

Harley CDG, Hughes AR, Hultgren KM, Miner BG, Sorte CJB, Thornber CS, et al. 2006. The impact of climate change in coastal marine systems. Ecology Letters, 9: 228-241. PMID:16958887. doi:10.1111/j.1461-0248.2005.00871.x.

Havenhand JN. 1995. Evolutionary ecology of larval types. In Ecology of marine invertebrate larvae. Edited by L McEdward. CRC Press, New York, New York. pp. 79-122.

Hebert PDN, Ratnasingham S, and deWaard JR. 2003. Barcoding animal life: cytochrome c oxidase subunit I divergences among closely related species. Proceedings of the Royal Society of London B, 270(Suppl): S96-S99. doi:10.1098/rsbl.2003.0025.

Helmuth B, Mieszkowska N, Moore P, and Hawkins SJ. 2006. Living on the edge of two changing worlds: forecasting the responses of rocky intertidal ecosystems to climate change. 
Annual Review of Ecology, Evolution, and Systematics, 37: 373-404. doi:10.1146/annurev. ecolsys.37.091305.110149.

Hewitt GM. 1999. Post-glacial recolonisation of European biota. Biological Journal of the Linnean Society, 68: 87-112. doi:10.1111/j.1095-8312.1999.tb01160.x.

Jennings RM, Shank TM, Mullineaux LS, and Halanych KM. 2009. Assessment of the Cape Cod phylogeographic break using the bamboo worm Clymenella torquata reveals the role of regional water masses in dispersal. Journal of Heredity, 100: 86-96. PMID:18790728. doi:10.1093/jhered/esn067.

Jensen JL, Bohonak AJ, and Kelley ST. 2005. Isolation by distance, web service. BMC Genetics, 6: 13. doi:10.1186/1471-2156-6-13.

Kelly DW, MacIsaac HJ, and Heath DD. 2006. Vicariance and dispersal effects on phylogeographic structure and speciation in a widespread estuarine invertebrate. Evolution, 60: 257-267. PMID:16610318. doi:10.1111/j.0014-3820.2006.tb01104.x.

Kenchington EL, Patwary MU, Zouros E, and Bird CJ. 2006. Genetic differentiation in relation to marine landscape in a broadcast-spawning bivalve mollusc (Placopecten magellanicus). Molecular Ecology, 15: 1781-1796. PMID:16689898. doi:10.1111/j.1365-294X.2006.02915.x.

Kimura M. 1980. A simple method for estimating evolutionary rates of base substitutions through comparative studies of nucleotide sequences. Journal of Molecular Evolution, 16: 111-120. PMID:7463489. doi:10.1007/BF01731581.

Lawton JH. 1993. Range, population abundance and conservation. Trends in Ecology \& Evolution, 8: 409-413. PMID:21236213. doi:10.1016/0169-5347(93)90043-O.

Layton KKS, Martel AL, and Hebert PDN. 2015. Geographic patterns of genetic diversity in two species complexes of Canadian marine bivalves. Journal of Molluscan Studies, 82: 282-291. doi:10.1093/ mollus/eyv056.

Librado P, and Rozas J. 2009. DnaSP v5: a software for comprehensive analysis of DNA polymorphism data. Bioinformatics, 25: 1451-1452. PMID:19346325. doi:10.1093/bioinformatics/btp187.

Marko PB. 2004. 'What's larvae got to do with it?' Disparate patterns of post-glacial population structure in two benthic marine gastropods with identical dispersal potential. Molecular Ecology, 13: 597-611. doi:10.1046/j.1365-294X.2004.02096.x.

Meehan BW. 1985. Genetic comparison of Macoma balthica (Bivalvia, Telinidae) from the eastern and western North Atlantic Ocean. Marine Ecology Progress Series, 22: 69-76. doi:10.3354/ meps022069.

Meirmans PG. 2012. The trouble with isolation by distance. Molecular Ecology, 21: 2839-2846. PMID:22574758. doi:10.1111/j.1365-294X.2012.05578.x.

Nikula R, Strelkov P, and Väinölä R. 2007. Diversity and trans-Arctic invasion history of mitochondrial lineages in the North Atlantic Macoma balthica complex (Bivalvia: Tellinidae). Evolution, 61: 928-941. PMID:17439622. doi:10.1111/j.1558-5646.2007.00066.x.

Owen EF, and Rawson PD. 2013. Small-scale spatial and temporal genetic structure of the Atlantic sea scallop (Placopecten magellanicus) in the inshore Gulf of Maine revealed using AFLPs. Marine Biology, 160: 3015-3025. doi:10.1007/s00227-013-2291-8. 
Palumbi SR. 2003. Population genetics, demographic connectivity, and the design of marine reserves. Ecological Applications, 13(1): S146-S158. doi:10.1890/1051-0761(2003)013[0146:PGDCAT]2.0. $\mathrm{CO} ; 2$.

Pappalardo P, Pringle JM, Wares JP, and Byers JE. 2015. The location, strength, and mechanisms behind marine biogeographic boundaries of the east coast of North America. Ecography, 38: 722-731. doi:10.1111/ecog.01135.

Partridge VA. 2001. Influence of ice cover on sediment temperature and implications for intertidal benthic invertebrates on a Bay of Fundy mudflat. In Proceedings 11th Workshop on River Ice. River ice processes within a changing environment. Ottawa, Ontario, Canada. pp. 14-16.

Pettigrew NR, Churchill JH, Janzen CD, Mangum LJ, Signell RP, Thomas AC, et al. 2005. The kinematic and hydrographic structure of the Gulf of Maine Coastal Current. Deep Sea Research Part II: Topical Studies in Oceanography, 52: 2369-2391. doi:10.1016/j.dsr2.2005.06.033.

Provan J, and Maggs CA. 2012. Unique genetic variation at a species' rear edge is under threat from global climate change. Proceedings of the Royal Society B: Biological Sciences, 279: 39-47. PMID:21593035. doi:10.1098/rspb.2011.0536.

Ramos-Onsins SE, and Rozas J. 2002. Statistical properties of new neutrality tests against population growth. Molecular Biology and Evolution, 19: 2092-2100. PMID:12446801. doi:10.1093/ oxfordjournals.molbev.a004034.

Rogers AR, and Harpending H. 1992. Population growth makes waves in the distribution of pairwise genetic differences. Molecular Biology and Evolution, 9: 552-569. PMID:1316531.

Rueffler C, Van Dooren TJ, Leimar O, and Abrams PA. 2006. Disruptive selection and then what? Trends in Ecology \& Evolution, 21: 238-245. PMID:16697909. doi:10.1016/j.tree.2006.03.003.

Scheltema RS. 1964. Feeding habits and growth in the mud-snail Nassarius obsoletus. Chesapeake Science, 5: 161-166. doi:10.2307/1350560.

Scheltema RS. 1967. The relationship of temperature to the larval development of Nassarius obsoletus (Gastropoda). Biological Bulletin, 132: 253-265. doi:10.2307/1539893.

Simonsen KL, Churchill GA, and Aquadro CF. 1995. Properties of statistical tests of neutrality for DNA polymorphism data. Genetics, 141: 413-429. PMID:8536987.

So JJ, Uthicke S, Hamel JF, and Mercier A. 2011. Genetic population structure in a commercial marine invertebrate with long-lived lecithotrophic larvae: Cucumaria frondosa (Echinodermata: Holothuroidea). Marine Biology, 158: 859-870. doi:10.1007/s00227-010-1613-3.

St-Onge P, Sévigny JM, Strasser C, and Tremblay R. 2013. Strong population differentiation of softshell clams (Mya arenaria) sampled across seven biogeographic marine ecoregions: possible selection and isolation by distance. Marine Biology, 160: 1065. doi:10.1007/ s00227-012-2157-5.

Sunday JM, Bates AE, and Dulvy NK. 2012. Thermal tolerance and the global redistribution of animals. Nature Climate Change, 2: 686-690. doi:10.1038/nclimate1539.

Tajima F. 1989. Statistical method for testing the neutral mutation hypothesis by DNA polymorphism. Genetics, 105: 437-460. 
Vucetich JA, and Waite TA. 2003. Spatial patterns of demography and genetic processes across the species' range: null hypotheses for landscape conservation genetics. Conservation Genetics, 4: 639-645. doi:10.1023/A:1025671831349.

Weersing K, and Toonen RJ. 2009. Population genetics, larval dispersal, and connectivity in marine systems. Marine Ecology Progress Series, 393: 1-12 . doi:10.3354/meps08287.

Wilkinson T, Wiken E, Bezaury-Creel J, Hourigan T, Agardy T, Herrmann H, et al. 2009. Marine ecoregions of North America. Commission for Environmental Cooperation, Montreal, Canada. $200 \mathrm{pp}$.

Wright S. 1943. Isolation by distance. Genetics, 28: 114. PMID:17247074. 